Article

\title{
Priority of Uses in International Water Law
}

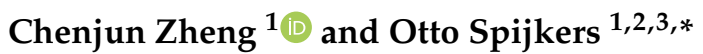 \\ 1 China Institute of Boundary and Ocean Studies (CIBOS), Wuhan University, Wuhan 430072, China; \\ zhengchenjun@whu.edu.cn \\ 2 Research Institute of Environmental Law, Wuhan University, Wuhan 430072, China \\ 3 International Water Law Academy, Wuhan University, Wuhan 430072, China \\ * Correspondence: ottospijkers@whu.edu.cn
}

Citation: Zheng, C.; Spijkers, O.

Priority of Uses in International Water

Law. Sustainability 2021, 13, 1567.

https://doi.org/10.3390/su13031567

Received: 18 December 2020

Accepted: 29 January 2021

Published: 2 February 2021

Publisher's Note: MDPI stays neutral with regard to jurisdictional claims in published maps and institutional affiliations.

Copyright: (c) 2021 by the authors. Licensee MDPI, Basel, Switzerland. This article is an open access article distributed under the terms and conditions of the Creative Commons Attribution (CC BY) license (https:/ / creativecommons.org/licenses/by/ $4.0 /)$.

\begin{abstract}
The raison d'être of international water law is that it provides States with a toolkit to equip them to deal with complex problems relating to the joint use and sustainable management of transboundary freshwater resources. The principle of equitable and reasonable utilization is one such tool in this toolkit. When applying the equitable and reasonable utilization principle to a specific transboundary watercourse, States sharing that watercourse must decide which water uses are more important than others. But the general rule is that no water use takes a priori priority over others (this is the so-called no-inherent-priority rule). This paper examines three ways in which this no-inherent-priority rule can be relativized, by recognizing a certain degree of priority to certain categories of water uses. Based on an assessment of previous State practice, it is suggested that (1) existing uses enjoy a certain degree of priority over new uses; that water uses that are (2) more beneficial to a greater number of people and are less damaging to other uses and the freshwater ecosystems, enjoy priority; and that water uses that (3) immediately satisfy vital human water needs enjoy priority. States need some general guidance in identifying which water uses normally take priority in defined circumstances, and this paper provides such guidance, thereby making the tool more effective. States can decide to derogate from these general rules if the circumstances so require; they are, of course, not legally binding on them.
\end{abstract}

Keywords: international water law; priority of uses; equitable and reasonable utilization

\section{Introduction}

Freshwater resources are essential for human survival. In most parts of the world, freshwater has been available in sufficient quality and quantity, and thus "freshwater" was not so much on people's minds. Due to environmental degradation and the negative impact of climate change, this is no longer the case for an increasing part of the world's population. And because there is no alternative resource that could replace water, this is a reason for alarm. Poor freshwater resources management poses a great threat to sustainable development; but if managed equitably and reasonably, water resources can serve as a catalyst for sustainable development [1].

In the case of transboundary freshwater resources-i.e., freshwater resources shared by two or more States-one often sees that the States concerned all try to do what is best to ensure the development of their own population, with a focus on their own present generation. Because of increasing water shortages, riparian countries are facing the pressure of survival and development, and there exist overlapping and competing claims to the use of one and the same freshwater resource. In this competition, the interests of future generations are often neglected. If there is no restriction on the water use behavior of riparian countries, the "sustainability" of water use will inevitably be damaged [2].

International water law was developed to provide States with a toolkit to equip them to deal with complex problems relating to the joint use and sustainable development of freshwater resources. These problems include water pollution, waste of water, water 
scarcity and droughts, damage to aquatic biodiversity and freshwater ecosystems, and flood-risk management [3]. All these problems are transboundary, i.e., they do not "respect" national borders [4]. One of the most important "tools", or principles of international water law, is the principle that obliges all States sharing a watercourse to utilize that international watercourse in an equitable and reasonable manner. This is the so-called "equitable and reasonable utilization" principle. This paper addresses the question whether, under general international water law, there is room for prioritizing certain water uses over others, when this "equitable and reasonable utilization" principle is applied to a specific transboundary watercourse.

The principle is codified in Article 5 of the Convention on the Law of the Nonnavigational Uses of International Watercourses (concluded in New York on 21 May 1997, entry into force on 17 August 2014, hereafter referred to as the UN Watercourses Convention). The entry into force of this Convention is important not only regarding the few States that have ratified it; its entry into force also affirms the customary international law status of the principles codified in the Convention, thus enabling every riparian State to use the Convention when claiming its basic rights and reminding other States of their basic duties regarding shared water resources [3].

There exists another global convention on the management of transboundary freshwaters, the Convention on The Protection and Use of Transboundary Watercourses and International Lakes, which was prepared under the auspices of the UN Economic Commission for Europe (UNECE) in 1992 (UNECE Water Convention). It complements the UN Watercourses Convention. As stated in Article 2, paragraph 2 (c), UNECE Water Convention, "the Parties shall, in particular, take all appropriate measures [ ... ] to ensure that transboundary waters are used in a reasonable and equitable way, taking into particular account their transboundary character, in the case of activities which cause or are likely to cause transboundary impact". The UNECE Water Convention thus supports the spirit of the principle of "equitable and reasonable utilization" as codified in the UN Watercourses Convention.

Article 6 of the UN Watercourses Convention contains a list of factors relevant to equitable and reasonable utilization. This list is non-exhaustive [5], and it makes explicit that "the weight to be given to each factor is to be determined by its importance in comparison with that of other relevant factors", and that, "in determining what is a reasonable and equitable use, all relevant factors are to be considered together and a conclusion [must be] reached on the basis of the whole". Article 10 UN Watercourses Convention, which deals with the relationship between different kinds of uses, adds that "in the absence of agreement or custom to the contrary, no use of an international watercourse enjoys inherent priority over other uses", and that "in the event of a conflict between uses of an international watercourse, [such a conflict] shall be resolved with reference to articles 5 to 7 [which contain the equitable and reasonable utilization principle and no harm rule, respectively], with special regard being given to the requirements of vital human needs". From this, one gets the impression that, to find an equitable and reasonable balance between different uses of the same watercourse, no use enjoys inherent or a priori priority over other uses. This is generally referred to as the no-inherent-priority rule.

Article 4 of the Draft Articles on the Law of Transboundary Aquifers, adopted by the International Law Commission (ILC) in 2008, declares the equitable and reasonable utilization principle applicable also to transboundary aquifers. Article 5 of these Draft Articles contains a list of factors relevant to equitable and reasonable utilization, which is very similar to the list contained in Article $6 \mathrm{UN}$ Watercourses Convention, already referred to above. Again, the list is not exhaustive, and it is once again made explicit that "the weight to be given to each factor is to be determined by its importance with regard to a specific transboundary aquifer or aquifer system in comparison with that of other relevant factors", and that "in determining what is equitable and reasonable utilization, all relevant factors are to be considered together and a conclusion reached on the basis of all the factors", with the exception that, "in weighing different kinds of utilization of 
a transboundary aquifer or aquifer system, special regard shall be given to vital human needs". Again, the no-inherent-priority rule applies.

The status of equitable and reasonable utilization as a general principle of customary international water law is largely undisputed, although it must be admitted that some scholars have recently challenged its sacrosanct status and have suggested that the no significant harm principle should be decisive in the resolution of transboundary freshwater disputes [6]. At the same time, it is still unclear what the principle means exactly, and how it should be applied in a concrete case. The International Court of Justice (ICJ) has not yet been presented with an opportunity to provide clarity on this issue. In the Gabčíkovo-Nagymaros case of 1997, the ICJ recognized for the first time the customary status of the principle but did not have occasion to provide detailed guidelines on how to interpret and apply it [7] (para. 85). More than ten years later, in the Pulp Mills case, the ICJ said something about the relevance of the principle in the interpretation and application of a bilateral treaty between Argentina and Uruguay, noting that the principle was essential to determine user rights to the watercourse enjoyed by both riparian States [8] (para. 177). Nevertheless, on the core issue of how to prioritize various uses of the river to reach an equitable and reasonable balance of uses, the ICJ has not made any clear pronouncements. Interestingly, Argentina proposed that its "existing use" should be granted priority treatment [8] (para. 170), but the ICJ did not embrace that argument. As demonstrated below, such arguments are often made.

How to deal with the relationship between different water uses is the main issue to be addressed by the priority of uses rule [9]. States can of course agree amongst themselves that certain uses of a particular transboundary watercourse that they share enjoy priority over others. That is perfectly possible, but this is not the topic of the present paper. Instead, this paper addresses the question whether, under general international water law, there is room for prioritizing certain water uses over others, when the principle of equitable and reasonable utilization is applied to a specific transboundary watercourse.

Figuring out the problem of how to prioritize certain water uses over others is essential in efforts to achieve sustainable development of a transboundary freshwater resource. This is because sustainable development requires a balance among different water uses and users. The concept of sustainable development by definition seeks to balance social, economic, and environmental uses within the present generation (intragenerational balance of uses), as these are the three pillars of sustainable development. It is especially in relation to the latter, that an intergenerational balance must also be sought between the interests of different users, i.e., the present generation of water users and the future generations of water users. There is plenty of evidence that the international community is aware of the importance of achieving such an intergenerational equitable balance of uses and users. The UN General Assembly declared 2018-2028 as the International Decade of action on "water for sustainable development" [10]. And target 4 of Sustainable Development Goal 6 urges States to "substantially increase water-use efficiency across all sectors and ensure sustainable withdrawals and supply of freshwater to address water scarcity" [11].

Even though the international community is aware of the urgency to provide States with the necessary guidance in their efforts to achieve an equitable balance of uses, the most authoritative formulations of the principle of equitable and reasonable utilization are not particularly helpful when it comes to the question of prioritizing water uses. Basically, there appears to be something of a "non-inherent priority" rule, which says that, generally, no particular use is naturally more important than another. The word "priority" has two distinct meanings in the vocabulary of (inter)national water law: if one use is said to have priority over another, it can mean that (1) the former is regarded as more important than the latter, or as requiring special attention. But it can also mean that (2) the former use was established "prior to" another, i.e., earlier in time, that it preceded the latter [12]. These are two different meanings of the term priority, that need to be clearly distinguished. To avoid confusion, this paper uses the term "priority" to refer primarily to the first category. When discussing the importance of time, reference is made to preferential treatment given to 
existing uses over future uses (especially in Sections 3.2 and 4.2, below). The other term that deserves attention is the adjective "inherent". If a water use has "inherent" priority, it could mean that such priority is fixed, permanent, intrinsic, context-independent, indefeasible, (deep) rooted and/or ingrained [13]. More will be said about what exactly "inherent priority" means in the context of international water law in Section 3.4, below.

A rule which says that no water use enjoys "inherent priority" over others is, albeit sensible, not particularly helpful in resolving controversies relating to conflicting demands and uses of the same transboundary river. It is, in other words, not a particularly effective "tool". That this is not an academic problem but an actual problem is illustrated by a case currently pending before the ICJ, relating to the Silala waters [14]. In this dispute, the conflict between different water uses was first raised in Chile's application instituting proceedings [15]. Basically, Chile was asking the ICJ to confirm the lawfulness of its current use of the Silala, based on the equity principle. If the ICJ has jurisdiction to deal with the merits of the case, it must address the priority of competing uses of the Silala, and it needs guidelines to do so. Are there such guidelines? Previous cases—the Gabčíkovo-Nagymaros and Pulp Mills cases already alluded to earlier-were based in part on specific watercourse agreements, and these agreements gave some indication on what uses were considered more important than others. The same can be said of the award issued in the Indus Waters Kishenganga Arbitration between the Islamic Republic of Pakistan and the Republic of India, which was based on an interpretation of the Indus Water Treaty of 1960 (more on this treaty and the award below, in Section 3.2). But in the Silala waters case, there is no such watercourse specific agreement, and all the ICJ can refer to, are the general principles of international water law and unwritten customary law.

The ICJ will thus be faced with this most complex and difficult aspect of the equitable and reasonable utilization principle, namely on what basis, and in what way, to decide which uses of a transboundary watercourse should take priority over others in case of conflict?

Although the flexibility of the equitable and reasonable utilization principle, as codified in Articles 6 and 10 of the UN Watercourses Convention, has been widely recognized and applauded, the ensuing "relativity" of the no-inherent priority rule is rarely mentioned. The objective of this paper is thus to look closer at the appearance of such "relativity". This paper looks at State practice, and at relevant legal instruments and soft law materials, to better understand this relativity in the application of the equitable and reasonable utilization principle, so that the principle might be easier applied in concrete cases.

This paper thereby provides some guidance to the Court, and to States facing a similar problématique, be it today or in the future. It examines three ways in which the no-inherent-priority rule can be relativized, by recognizing a certain degree of priority to certain categories of water uses. Based on an assessment of previous State practice, it is suggested that (1) existing uses enjoy a certain degree of priority over new or future uses; that (2) water uses that are more beneficial to a greater number of people and are less damaging to other uses and the freshwater ecosystems, enjoy priority; and that (3) water uses that immediately satisfy vital human water needs enjoy priority. It is our conviction that States need some general guidance on what uses normally take priority in defined circumstances, and this paper purports to provide that. States can decide to derogate from the three priority dimensions listed just above-and developed in more detail in Section 4, below-if the circumstances so require.

\section{Research Methodology and Sources Used}

The focus of our research is on the UN Watercourses Convention and the Rules relating to the Uses of the Waters of International Rivers, which were adopted by the International Law Association (ILA) in 1966 (hereafter referred to as Helsinki Rules). This is because those documents provide the most authoritative statement of the principle of equitable and reasonable utilization, as derived from the materials of custom, i.e., State practice and opinio iuris. The UN Watercourses Convention is a multilateral treaty, but it did not 
purport to create new rights and obligations, but mainly to codify already existing ones. In fact, the text of the Convention was prepared by the ILC, and the Commission based that text on an in-depth study of already existing customary international water law, with only some elements of progressive development added to it [3,16] (p. 81). Article 5 and 6 and 10 UN Watercourses Convention, which are most relevant for present purposes, were certainly meant to codify already existing customary law, and not to create new rights and obligations. This is clearly illustrated by the following: the ILC's second special rapporteur on international water law, Stephen Schwebel, concluded, after a through and in-depth study of numerous authoritative interpretations of State practice, that in the context of disputes between States concerning the use and planned exploitation of shared watercourses, almost all the relevant comments and statements consider "equitable and reasonable use" a general principle of customary international law [17](paras. 41-110). In this paper, all the treaties and other documents supporting the view that the equitable and reasonable utilization principle is a general principle of customary international water law are not analyzed in-depth once again. Instead, reference is made to the abundance of evidence collected by Schwebel and many others.

This paper examines the text, accompanying commentaries, and travaux préparatoires of the UN Watercourses Convention and the ILA's Helsinki Rules, as well as relevant domestic and international case law, and soft law documents (primarily world summit outcome documents and United Nations General Assembly resolutions). Finally, reference will be made to relevant scholarly literature and the most authoritative commentaries.

The structure of this paper is as follows: first, based on the sources listed just above, a history of the emergence of the no-inherent-priority rule is offered (Section 3). The paper then identifies three ways in which this rule has been interpreted and applied in a flexible manner, i.e., three priority dimensions (Section 4). In other words, certain uses do have a certain degree of priority. Existing water uses appear to have some priority over new and potential water uses. Second, water uses that are beneficial to a larger group of people, and are less damaging to competing water uses, enjoy a certain degree of priority. And third and finally, water uses that immediately satisfy vital human water needs enjoy priority over other water uses. This paper ends with a brief conclusion (Section 5).

\section{The No-Inherent Priority Rule}

\subsection{How Navigational Use Lost Its Priority Status}

In the early days, the use of watercourses for navigation was given priority over other uses of the watercourse. Influenced by the powerful transportation function of the Nile, Indus, Amazon etc., systematic navigation rules were developed in history. These rules dominated non-navigational rules for a long time before at least the 1900s [18]. This was a general rule, applicable to all the world's watercourses. Even after the 1900s, this is reflected in the Madrid Declaration, adopted by the Institut de droit international in 1911, as follows:

"Lorsqu'un cours d'eau traverse successivement les territoires de deux ou de plusieurs États [ ... ] Le droit de navigation en vertu d'un titre reconnu en droit international ne peut pas être violé par un usage quelconque" [19].

An expression such as "may not be violated in any way whatever" clearly reflects the general recognition of the "inherent priority" of the right to navigation by the international community under the historical conditions of the time.

However, with the acceleration of industrialization and the growth of the world's population, the demand for freshwater continuously grew. Especially, increasing agricultural water demand (particularly irrigational water) made the importance of non-navigational water uses more and more prominent [20]. Meanwhile, various alternative modes of transport-by road, air, etc. were developed, which led to a relative decline in the importance of river navigation, and the attention has gradually shifted to non-navigational water uses. 
An early example is the Utilization of Waters of the Colorado and Tijuana Rivers and of the Rio Grande, a treaty concluded between the United States of America (USA) and Mexico in 1944. Even though the right of navigation constituted an existing use, the treaty accepted that the right may have to give way to other uses. In fact, the parties had agreed on a pre-set "order of preferences". And of the seven uses listed therein, navigation only ranked fifth:

"In matters in which the [International Boundary and Water Commission] may be called upon to make provision for the joint use of international waters, the following order of preference shall serve as a guide:

1. Domestic and municipal uses.

2. Agriculture and stock raising.

3. Electric power.

4. Other industrial uses.

5. Navigation.

6. Fishing and hunting.

7. Any other beneficial uses which may be determined by the Commission" (emphasis added) [21].

Subsequently, in the emergence of the principle of equitable and reasonable utilization, the international community agreed that no water use, including navigation, will automatically and always take priority over other water uses. The most equivocal pronouncement of this approach can be found in the ILA's Helsinki Rules. Article VI proclaims as follows:

"A use or category of uses is not entitled to any inherent preference over any other use or category of uses" [22] (Art. VI, p. 491).

Many years after their promulgation, the Helsinki rules have continued to guide the settlement of water disputes among riparian States. They have also played an irreplaceable role in the subsequent development of international water law, especially in the codification of the UN Watercourses Convention [23]. From the accompanying commentary, it becomes clear that navigation may have enjoyed priority treatment in the past, but that "today, neither navigation nor any other use enjoys such a preference" [22] (Art. VI, Commentary, p. 491). Furthermore, it is noted that "it has been said that domestic use has succeeded navigation as a preferential use [but] substantial authority supporting the proposition has not been found" [22] (Art. VI, Commentary, p. 491). Indeed, "the granting of such a preference would be inconsistent with a principle of equitable utilization which relies on an inductive process of determination" [22] (Art. VI, Commentary, p. 491). At the same time, the ILA acknowledged that "if a domestic use is indispensable - since it is, in fact, the basis of life-it would not have difficulty in prevailing on the merits against other uses in an evaluation of the drainage basin" [22] (Art. VI, Commentary, pp. 491-492). More on this below (Section 4.4).

It has gradually become accepted that, at the level of general principles of international water law, navigational priority is no longer "inherent", and that no other water use enjoys such status. It is further accepted that no riparian country's water claims are naturally superior to those of other countries [24].

\subsection{How Existing Water Uses Lost Their Priority Status}

International water law never recognized a rule stating that whoever takes the water first thereby acquires an established right to use it forever. A theory of prior appropriation, which seems to suggest something along these lines, was once popular in the USA [25], but it was never adopted or applied in international law [26]. At the same time, there exist plenty of agreements giving some preferential treatment to existing uses over new uses. For example, Austria and the Czechoslovak Republic concluded an agreement granting new rights in respect of waterways and the construction of new hydraulic installations, which reads as follows: 
"Each of the two States is entitled in principle to dispose of half of the water flowing through frontier waterways. [ ... ] The exercise of rights acquired by the Contracting States on the strength of the above shall in no way prejudice rights already acquired" [27] (Article 28).

In other words, both States could engage in new water projects, as long as existing water uses were not negatively affected by those newly undertaken water projects in any way.

Most documents of authority evidence a more flexible and less categorical approach. For example, the Convention Relating to The Development of Hydraulic Power Affecting More Than One State proclaims as follows:

"Should reasonable development of hydraulic power involve international investigation, the Contracting States concerned shall agree to such investigation, which shall be carried out conjointly at the request of any one of them, with a view to arriving at the solution most favorable to their interests as a whole, and to drawing up, if possible, a scheme of development, with due regard for any works already existing, under construction, or projected" (emphasis added) [28] (Article 2).

Another example of the more flexible and balanced approach is provided in the Indus Waters Treaty, concluded in 1960 between India and Pakistan. This treaty gave India the right to build new hydro-electric projects, but India had to do so in such a way to avoid damaging Pakistan's existing agricultural and hydro-electric water uses [29] (pp. 148-161). Again, this evidences a more nuanced, context-specific approach to the clash between existing and new uses of the same watercourse.

At best, one can conclude from the above that existing water uses were-and sometimes still are-granted a certain and context-dependent "priority", but clearly not an inherent or absolute priority.

\subsection{Emergence of the No-Inherent Priority Rule}

As mentioned above, the UN Watercourses Convention, especially in its Articles 5, 6, and 10 read together, makes clear that no particular use of transboundary waters enjoys a priori priority over others. Instead, the importance of each use is to be determined by comparing it with that of other uses in the particular circumstances [30]. In determining what is a reasonable and equitable use, all relevant factors are to be considered together, and a conclusion must be reached on the basis of the whole (this is referred to as the factors approach) [31]. In other words, no factor has a fixed weight, no use has a fixed importance, nor will all factors be relevant in all cases.

Based on this reasoning, Article 10 UN Watercourses Convention concludes that "no use of an international watercourse enjoys inherent priority over other uses". The factors approach, with the non-inherent priority rule as its foundation, has been widely accepted by experts, aiming to explain the lack of a predetermined ranking in various water uses [16] (p. 50). This approach is inspired by the ILA's Helsinki Rules, already referred to above. States were positive about this approach. Speaking in a general sense about the ILC's first draft of the UN Watercourses Convention, the Chinese representative said that the draft articles "represented a realistic, balanced approach to the need to reconcile the different interests of watercourse States" [32] (para. 42 (p. 9)). This balanced interest also stems from the fact that riparian states have reciprocal interests regarding their international rivers, and they are committed to protecting their own interests from those of other parties [33].

At the same time, the reason these rules exist is to avoid and resolve transboundary conflicts. This raises the question how helpful a non-inherent priority rule is in avoiding and resolving conflicts over shared waters between the upstream and downstream States. The water use relationship between upstream and downstream countries is like a zero-sum game, which cannot be truly reconciled $[34,35]$. Due to the introduction of the obligation not to cause harm (the so called "no harm" rule), the downstream countries which developed 
earlier can obtain unrestricted access to water benefits [36]. This also creates potential risk of conflict between upstream and downstream countries.

A priority-rule could potentially provide guidance to watercourse States in the case of conflicts involving two or more water uses, but a non-inherent-priority rule does not appear particularly helpful in such a scenario.

One reason to justify the inclusion of the no-inherent priority rule in the UN Watercourses Convention is that the UN Watercourses Convention was meant to operate as a so-called "framework" convention. And thus, its aim is to enact the basic principles and set forth the conceptual basis for eventual bilateral or regional arrangements regarding specific watercourses to be concluded between the watercourse States concerned, considering their respective characteristics. Seen in this way, the non-inherent priority rule of the UN Watercourses Convention could be perceived to invite States to agree on prioritizing of uses, considering the particularities of the watercourse they share. And States may wish to revisit this issue, as circumstances may change, requiring them from time to time to reprioritize the different uses of their shared transboundary watercourses [37] (Article 10, Commentary, pp. 109-110).

To conclude, a fixed priority of uses would perhaps provide some predictability and consistency to the principle of equitable and reasonable utilization, but if one particular use would always take unconditional priority over all other uses, regardless of the particularities of the watercourse concerned, then equal rights to other uses could be jeopardized or threatened.

\subsection{Meaning of the No-Inherent-Priority Rule}

It might be helpful, at this stage of our analysis, to look more closely at the term "inherent" in "inherent-priority". In a general sense, an "inherent" right is a right one has regardless of whether some external entity or source has conferred it. This suggests that inherent user rights are acquired "naturally". Indeed, the investigation of the validity of inherent rights usually requires the historical approach to trace the emergence and evolution of rights [38,39]. Proof of the existence of such rights generally does not lie in the fact that they have been, at one point or another, formally claimed, but rather in the fact that they have been enjoyed for a considerable period. Inherent user rights are thus reflected in longstanding water allocation practices, which many people have been relying on for generations. Even if such uses might not be particularly sustainable, the fact that they have existed for generations leads to a certain degree of tolerance and understanding. Seen in this way, inherent rights are rights established through custom.

The ILC's attitude towards such rights is a bit ambiguous. It held that no use of an international watercourse has an inherent priority for other uses, while at the same time protecting the priority of uses in existing agreements or custom. This is reflected in Article 10 UN Watercourses Convention.

Not all States were equally happy with this approach [40]. When the provision was discussed, some States objected to the reference to "custom", arguing that the term "custom", if included in the article, would give priority to existing water uses and might eventually lead to abuse. As the delegation of the Netherlands said in its comments on the ILC's draft articles of the UN Watercourses Convention:

“The words 'or custom' in paragraph 1 of [Article 10] should be deleted or at any rate qualified. In its present form, article 10 could lead to absolute priority being given to existing uses over new uses. The Netherlands Government regards this as an undesirable construction. Moreover, such a priority would not be consistent with article 6, paragraph 1 , which stipulates that existing uses constitute only one of the factors to be taken into consideration. This is, of course, different if the protection of existing uses is based on a rule of (regional) customary law" [41] (para. 17 (p. 5)).

These concerns of the Netherlands were perhaps a bit exaggerated. The ILC only meant to refer to situations in which "there may be no 'agreement' between watercourse 
States but where, by tradition or in practice, they have given priority to a particular use" [16] (Article 10, Commentary, p. 110). Such customs should be perceived as unwritten agreements between the riparian States concerned [42]. The ILC did not mean to refer to unilateral customs, i.e., practices that have existed in one State only and have emerged without inter-State consultation or consent. States may agree amongst each other to give certain water uses priority treatment through such existing practices or custom [43] (p. 53).

Since an existing "custom" can thus prioritize a particular water use, it thereby confirms that the non-inherent priority rule does allow for exceptions. Because of the great variety amongst the world's traditions and cultures relating to water use, there is also a great variety amongst those unwritten agreements on what use deserves inherent priority treatment [44]. The UN Watercourses Convention respects this. At the same time, there is no reason to interpret Article $10 \mathrm{UN}$ Watercourses Convention as suggesting that local customs can go against the very essence of the equitable and reasonable utilization principle. Article 10 features at the very end of Part II of the UN Watercourses Convention, on General Principles. Clearly, the essence of this part consists of the principles themselves, i.e., Articles 5 and 7 . Article 10 was only intended to allow for a limited possibility to adapt these principles to local particularities.

\subsection{Importance of Procedural Fairness in Absence of a Priority Rule}

Clearly, the consensus that no water use, not even navigational or domestic water use, has a priori or inherent priority over other uses, does not help much in resolving conflicts over the use of transboundary waters. States have tried to grapple with this problem by concluding watercourse specific agreements, i.e., bilateral or multilateral treaties regulating the use of a particular watercourse only. These agreements attempted to avoid—or resolve-conflicts between upstream and downstream States over the right to use the same watercourse.

If no such agreement is reached beforehand on how different uses should be prioritized, then the procedure through which disputes need to be resolved becomes even more crucial. The Lake Lanoux Arbitration between France (upstream) and Spain (downstream State) nicely illustrates the way in which an international arbitral tribunal tried to ease the tensions by requiring of both States to negotiate in good faith instead of bluntly relying on their rights to use the water, and to give the other State notice of planned activities, where such activities might affect the interests of the other riparian State [45]. This seems a sensible way out: if conflicts over different water uses cannot be resolved beforehand, then the procedural requirements of cooperation, notification, consultation, providing and sharing of information, etc. become ever more crucial [46]. For example, in the San Juan River cases (decisions of 2015 and 2018), the International Court of Justice specified in its judgments the obligations of notification and consultation to ensure the proper implementation of an Environmental Impact Assessment and to prevent and mitigate the risk of cross-border impacts [47] (para. 104).

\section{Three Priority Dimensions}

\subsection{Three Dimensions for "Priority of Uses"}

From the above analysis, it can be concluded that the priority issue arises in two ways: priority between different types of uses, and priority between existing and future uses. Even though the starting point in both cases is the no-inherent-priority rule, in practice this rule is nuanced a bit, by providing a certain degree of priority, to the extent appropriate in the circumstances, to some types of uses, and to existing uses. In other words, the no-inherent-priority rule is not absolute, but is relative, i.e., its rigidity is dependent on the circumstances.

Further support for this can be found in Article 6, paragraph 1 (g) of the UN Watercourses Convention, which lists "the availability of alternatives, of comparable value, to a particular planned or existing use" as one relevant factor to consider when utilizing an international watercourse in an equitable and reasonable manner. This refers to two 
different types of alternatives: alternative water sources to draw from, and alternative means to satisfy the water needs concerned [37] (Article 6, Commentary, p. 101). This inter alia encourages States to revisit existing practices and look for more sustainable alternatives [48]. This relativizes the reliance on existing uses as basis for a perpetual or prioritized user right.

Looking at existing State practice and case law, this study found three dimensions in which the priority of uses principle still manifests itself, to a certain degree, despite the assumption that in theory, no water use has inherent priority over any other use. First, there still appears to be some traces of preferential treatment of existing uses over new and potential uses. Second, water uses that are generally more beneficial and less damaging tend to get preferential treatment. And third and finally, it seems that uses that immediately satisfy basic water needs also get priority treatment.

\subsection{Dimension 1: Existing Uses}

At what point in time does a particular use of a watercourse become an "existing" use? This issue was already addressed in the ILA's Helsinki Rules [22] (Art. V-VIII, Commentary, pp. 488-494). There, the importance of establishing the moment in time at which a use emerged was emphasized. Crucially, a particular use cannot be considered as "existing" until it is operational [23]. In other words, a water use which is still in the planning phase does not "exist" yet [22] (Art. VIII, Commentary, p. 494).

After stating the general rule, i.e., that no use or category of uses is entitled to any inherent preference over any other use or category of uses (Article VI), the ILA Helsinki Rules immediately added that "a basin State may not be denied the present reasonable use of the waters of an international drainage basin to reserve for a co-basin State a future use of such waters" (Article VII). Further details are provided in Article VIII, as follows:

"1. An existing reasonable use may continue in operation unless the factors justifying its continuance are outweighed by other factors leading to the conclusion that it be modified or terminated so as to accommodate a competing incompatible use.

2. (a) A use that is in fact operational is deemed to have been an existing use from the time of the initiation of construction directly related to the use or, where such construction is not required, the undertaking of comparable acts of actual implementation.

(b) Such a use continues to be an existing use until such time as it is discontinued with the intention that it be abandoned.

3. A use will not be deemed an existing use if at the time of becoming operational it is incompatible with an already existing reasonable use" [22] (Art. VIII, p. 493).

An existing use only terminates when it is fully abandoned [49], meaning "the discontinuance of the use coupled with the intention to relinquish it" [50]. Thus, the mere failure to use the water for a while will not necessarily constitute abandonment [51].

In actual practice, sometimes disputes arise as to what the term "existing use" means exactly. In a dispute between Pakistan and India, already referred to above, India at some point during the controversy argued that an "existing use" was really the same as a "historic" use, i.e., a use that had manifested itself over a certain period of time and was in some way ingrained in a local culture and tradition [29] (para. 234). This view was not adopted by the Arbitral Panel; an existing use need not have lasted for generations to be granted a certain degree of priority treatment.

\subsection{Dimension 2: Benefit and Damage}

Some water uses are more beneficial than others and cause less damage to other water uses. The term "beneficial" should be understood broadly. It can refer to better quality of the water services provided, but also to the number of beneficiaries the service is provided to (the more, the better). 
The term "damage" should also be understood in the broadest sense [52]. It can refer to damage caused to other, competing water uses; but it may equally refer to damage caused to the watercourse, or the entire freshwater ecosystem. Water uses that are more beneficial and less damaging in this broad sense may deserve some preferential or priority treatment. Clearly, this may come into conflict with the priority granted to existing uses over new uses. This is because, in many cases, the new use may benefit from recent scientific innovations, and may thus be more sustainable, and less damaging to the watercourse's ecosystem, than historical or existing uses. And thus, if a potential use creates more benefits, it can weaken the claim to priority of an "existing use".

Stephen C. McCaffrey referred to this as the harm-benefit balancing test, which he derived mainly from case law of the United States federal courts, in particular the case decided by the US Supreme Court already in 1907 between Kansas and Colorado. From this case, McCaffrey concluded that:

"Colorado v New Mexico teaches that according to the principle of equitable utilization, each state has an equal right to an equitable portion of the uses and benefits of a shared watercourse, irrespective of where the watercourse rises, or which state's use was prior in time. New upstream uses may be permissible even where existing downstream uses fully consume the stream's waters. This may be the case, for example, where the benefits of a new use (e.g., providing food and electricity needed to alleviate poverty in the state making the use) substantially outweigh the harm that might result from it (e.g., reduction in the production of agricultural products for export in a state with relatively high living standards)." [46] (pp. 457-458)

A watercourse State's legal liability stems from its failure to take reasonable measures to prevent transboundary harm. However, it should also be recognized that a certain cross-border damage can continue to exist because the damage is offset by benefits, thus an equitable balancing of interests is created [53]. Sometimes, disputes can be resolved simply by tolerating that a new use has some negative effects on existing uses, on the condition that those people benefiting from the new use provide compensation for the damage caused by this new use to existing uses.

\subsection{Dimension 3: Vital Human Needs}

As an important material basis to maintain life, water plays an irreplaceable role. Human demand for water is manifested in economic activities such as drinking [54], municipal construction, and land development. Among them, water for agriculture or animal husbandry accounts for about $85 \%$ of human water demand [55]. Not all these water uses for human needs are of equal importance.

There is considerable support for the position that water uses for the satisfaction of people's immediate vital water needs take priority over other water uses [56]. This should be interpreted restrictively, because one could argue that ultimately all water uses benefit people's water needs. The priority should thus be limited to water needed basically to stay alive.

This is not the same as water use for "domestic water needs", which also includes water needed to fill a swimming pool in someone's private backyard. The category of water use for "vital human needs" includes water needed in agriculture to produce food for survival (but not to produce food which is exported for profit), which cannot be said to constitute water use for "domestic water needs". For these reasons, the UN Watercourses Convention does not recognize the priority of "domestic use", whilst it does grant priority treatment to uses intended to satisfy vital human water needs. It follows herewith the approach of the ILA's Helsinki Rules [22] (Art. VI, Commentary, p. 491).

Article 10 UN Watercourses Convention states that "special regard" should be "given to the requirements of vital human needs". During the codification of the UN Watercourses Convention, the United Kingdom asked whether the term "vital human needs" was sufficiently precise: 
"The United Kingdom doubts whether the reference in paragraph 2 to 'vital human needs' is sufficiently specific to perform a useful function additional to the criteria already specified in the article. If the intention of this paragraph is to assign priority to the satisfaction of specific vital human needs, such as the availability of clean drinking water, then it would be preferable to redraft the article so as to make specific reference to such needs" [57] (para. 16 (p. 36)).

In reply, the ILC made it clear that this requires that "special attention is to be paid to providing sufficient water to sustain human life, including both drinking water and water required for production of food in order to prevent starvation" [37] (Article 10, Commentary, p. 110).

The importance of satisfying vital human water needs was reaffirmed by the ILA in its Berlin Rules, adopted in 2004. The rule dealing with the issue of preferences among water uses, proclaims as follows:

"1. In determining an equitable and reasonable use, States shall first allocate waters to satisfy vital human needs.

2. No other use or category of uses shall have an inherent preference over any other use or category of uses." [58] (Rule 14, pp. 363-364).

This minimum requirement-satisfaction of vital human needs-is often linked to the human right to water [59-61]. Of the three dimensions, this one is perhaps the strongest claim to priority treatment. The human right to water must be realized by qualified fresh water supply. In international river basins, freshwater resources are always in a state of flow and cross political boundaries; in many cases of water shortage, freshwater resources are not reasonably distributed to all riparian countries, which has brought negative impacts on the realization of water rights. Therefore, watercourse States need to consider the human right to water of people situated in other riparian countries when they conduct water allocation [62].

In other words, the priority accorded to the satisfaction of "vital human needs" must be presumed and can only be refuted based on the specific circumstances of individual cases. This means that States cannot undermine the right to water for vital human needs of the people within their jurisdiction and control—and this might also include people within the territorial jurisdiction of other riparian states-on the grounds that this may benefit their water-related economic interests.

At the same time, the priority of satisfying immediate vital human water needs is not absolute [40]. Most importantly, it might clash with obligations of "sustainable use", as found in Article 5 (1) UN Watercourses Convention, and in the Convention's preamble, which stresses the importance of "the promotion of the optimal and sustainable utilization thereof for present and future generations". In a time of climate change, droughts, and water scarcity, this is a very real dilemma. The 1992 Rio Declaration on Environment and Development takes as starting point that "human beings are at the center of concerns for sustainable development" and that they are "entitled to a healthy and productive life in harmony with nature" [63] (Principle 1). This right belongs both to present and future generations. Article 10(2) UN Watercourses Convention should thus be read, not in the sense that immediate vital human water needs of the present generation always take priority over the vital human water needs of future generations, but that some intergenerational balance needs to be sought.

\section{Conclusions}

International water law has a purpose: it is a toolkit that is meant to be used to achieve something. International water law must equip States to jointly and sustainably manage the freshwater resources that they share. One of the tools in this toolkit is the principle of equitable and reasonable utilization. This tool, so this study argues, is only effective, if it provides enough guidance to States on how to achieve an equitable and reasonable result. This study has argued that the no-inherent-priority rule does not help much in providing 
such guidance, and thus an outlook of relativization should be included, so to speak, of this rule. To conclude, certain uses-existing uses, uses that are more beneficial and less damaging, and uses that satisfy vital human needs of present and future generations-do indeed deserve a certain degree of priority treatment.

Author Contributions: Conceptualization, C.Z.; methodology, C.Z. and O.S.; writing-original draft preparation, C.Z.; writing-review and editing, C.Z. and O.S.; supervision, O.S.; funding acquisition, O.S. Both authors have read and agreed to the published version of the manuscript.

Funding: This research received no external funding.

Data Availability Statement: No new data were created or analyzed in this study. Data sharing is not applicable to this article.

Conflicts of Interest: The authors declare no conflict of interest.

\section{References and Notes}

1. Yildiz, D. The Importance of Water in Development. World Water Dipl. Sci. News 2017, 10006, 1-7.

2. Rieu-Clarke, A.; Moynihan, R.; Magsig, B.O. UN Watercourses Convention User's Guide; IHP-HELP Centre for Water Law, Policy and Science (under the auspices of UNESCO): Dundee, UK, 2012.

3. Salman, S.M. Entry into Force of The UN Watercourses Convention: Why Should It Matter? Int. J. Water Resour. Dev. 2015, 31, 4-16. [CrossRef]

4. Hödl, E. Legislative Framework for River Ecosystem Management on International and European Level. In Riverine Ecosystem Management; Springer: Cham, Switzerland, 2018; pp. 325-345.

5. Mahbub, N.T. The Role of Proportionality in the Law of Transboundary Waters. Rev. Eur. Comp. Int. Environ. Law 2020, 29, 1-12.

6. Meshel, T. Swimming against the Current: Revisiting the Principles of International Water Law in the Resolution of Fresh Water Disputes. Harv. Int. Law J. 2020, 61, 135-184. [CrossRef]

7. ICJ. Gabčíkovo-Nagymaros Project (Hungary/Slovakia). Judgment of 25 September 1997.

8. ICJ. Pulp Mills on the River Uruguay (Argentina v. Uruguay). Judgment of 20 April 2010.

9. United Nations. Proposals for a Priority Programme of Coordination in the Field of Water Resources within the Framework of The United Nations Development Decade, in Official Records of the Economic and Social Council, August 1963. In Proceedings of the Thirty-Sixth Session, Annexes, agenda item 6. E/3760, New York, NY, USA, 2 July-2 August 1963.

10. United Nations General Assembly. International Decade for Action, "Water for Sustainable Development", 2018-2028; UNGA A/RES/71/222; Resolution adopted by the General Assembly on 21 December 2016; United Nations Publication: New York, NY, USA.

11. United Nations General Assembly. Transforming Our World: The 2030 Agenda for Sustainable Development; UNGA A/RES/70/1; Resolution adopted by the General Assembly on 25 September 2015; United Nations Publication: New York, NY, USA.

12. Priority, $n$. and adj; OED Online; Oxford University Press: Oxford, UK, September 2020.

13. Inherent, adj. and n; OED Online; Oxford University Press: Oxford, UK, September 2020.

14. Spijkers, O. Participation of Local Stakeholders in the Use of the Waters of the Silala. In New Zealand Yearbook of International Law; Brill: London, UK, 2021.

15. ICJ. Dispute over the Status and Use of the Waters of the Silala (Chile v. Bolivia), Chile's Application instituting proceedings. 6 June 2016.

16. Tanzi, A. The Economic Commission for Europe Water Convention and the United Nations Watercourses Convention: An Analysis of Their Harmonized Contribution to International Water Law; United Nations: New York, NY, USA, 2015.

17. Schwebel, S. Third Report on the Law of the Non-Navigational Uses of International Watercourses; UN Doc A/CN.4/348; United Nations Publication: New York, NY, USA, 11 December 1981.

18. McCaffrey, S.C. The Evolution of International Law Relating to Transboundary Waters. In Routledge Handbook of Water Law and Policy; Rieu-Clarke, A., Allen, A., Hendry, S., Eds.; Routledge: London, UK, 2017; pp. 205-217.

19. Institut De Droit International. Réglementation Internationale de L'usage des Cours d'eau Internationaux en Dehors de L'exercice du Droit de Navigation; Adopted in Madrid on 20 April 1911; Institut De Droit International: Geneva, Switzerland, 1911.

20. Lee, G.E.; Rollins, K.; Singletary, L. The Relationship between Priority and Value of Irrigation Water Used with Prior Appropriation Water Rights. Land Econ. 2020, 963, 384-398. [CrossRef]

21. Utilization of Waters of the Colorado and Tijuana Rivers and of the Rio Grande, Treaty between the United States of America and Mexico; Signed at Washington on 3 February 1944; United States Government Printing Office: Washington, DC, USA.

22. International Law Association. Uses of Waters of International Rivers. In International Law Association Reports of Conferences (Volume 52, Helsinki Conference); International Law Association Publication: London, UK, 1966.

23. Bogdanović, S. The International Law Association Helsinki Rules: Contribution to International Water Law. Brill Res. Perspect. Int. Water Law 2019, 3, 1-110. [CrossRef] 
24. Alsaadi, S.A.K.; Khalid, R.M.; Dahalan, W.S.A.W. Issues and Principles on Non-Navigational Use of International Watercourses. J. Undang-Undang Dan Masy. 2020, 26, 57-64. [CrossRef]

25. Arizona v. California. 283 U.S. 423, 459, 1931.

26. MacDonnell, L.J. Prior appropriation: A reassessment. U. Denver Water Law Rev. 2014, 18, 228-311. [CrossRef]

27. Treaty between the Republic of Austria and the Czechoslovak Republic. In Regarding the Settlement of Legal Questions Connected with Their Frontier; Signed at Prague on 12 December 1928.

28. Convention Relating to the Development of Hydraulic Power Affecting More Than One State; Concluded in Geneva on 9 December 1923; The League of Nations: Geneva, Switzerland.

29. Court of Arbitration Constituted in Accordance with the Indus Waters Treaty of 1960 (Islamic Republic of Pakistan v. The Republic of India), Partial Award, 18 February 2013.

30. McIntyre, O. Water, Law and Equity. In The Human Face of Water Security; Springer: Cham, Switzerland, 2017; pp. 45-70.

31. Tanzi, A.M. The Inter-Relationship between No Harm, Equitable and Reasonable Utilisation and Cooperation under International Water Law. Int. Environ. Agreem. Politics Law Econ. 2020, 20, 619-629. [CrossRef]

32. United Nations General Assembly. Agenda Item 144: Convention on the Law of the Non-Navigational Uses of International Watercourses (Summary Record of the 12th Meeting of Sixth Committee of the UN General Assembly); United Nations Publication: New York, NY, USA, 1996; A/C.6/51/SR.12.

33. Devlaeminck, D.J. Reciprocity and China's Transboundary Waters: The Law of International Watercourses; Routledge: New York, NY, USA, 2020

34. Phillips, D.; Attili, S.; McCaffrey, S.; Murray, J. Water and the Jordan River Co-Riparians: From a Zero-Sum to a Positive-Sum Game; Presentation given at the First Workshop on Hydro-Hegemony; London Water Research Group: London, UK, 2005.

35. Lemma, S. Cooperating on the Nile: Not a Zero-Sum Game. UN Chron. 2001, 38, 65-66.

36. Wegerich, K.; Olsson, O. Late Developers and the Inequity of "Equitable Utilization" and the Harm of "Do No Harm". Water Int. 2010, 35, 707-717. [CrossRef]

37. International Law Commission. Draft Articles on the Law of the Non-Navigational Uses of International Watercourses and Commentaries Thereto and Resolution on Transboundary Confined Groundwater; A/CN.4/SER.A/1994/Add.1. In Yearbook of the International Law Commission; International Law Commission: Geneva, Switzerland, 1994; Volume II, Part Two.

38. Alder, M.C. The Inherent Right of Self-Defence in International Law; Springer Science \& Business Media: Berlin, Germany, 2012.

39. Alder, M.C. The Origin in International Law of the Inherent Right of Self-Defence and Anticipatory Self-Defence. West. Aust. Jurist 2011, 2, 107-128.

40. Castillo-Laborde, L. Relationship between Different Kinds of Uses (Article 10). In The UN Convention on the Law of the NonNavigational Uses of International Watercourses: A Commentary; de Chazournes, L.B., Mbengue, M., Sangbana, K., Tignino, M., Eds.; Oxford University Press: Oxford, UK, 2018.

41. International Law Commission. Comments and Observations Received from The Netherlands, UN Doc. A/CN.4/447/Add.3. In Yearbook of the International Law Commission; International Law Commission: Geneva, Switzerland, 4 June 1993; Volume II, Part One.

42. International Law Commission. ILC Draft Conclusions on Identification of Customary International Law, with Commentaries, A/73/10. In Yearbook of the International Law Commission; International Law Commission: Geneva, Switzerland, 2 July 2018; Volume II, Part Two.

43. United Nations. Water and sustainable development from vision to action, means and tools for implementation and the role of different actors. In Report of the 2015 UN-Water Zaragoza Conference; United Nations Publication: New York, NY, USA, 2015.

44. Zareie, S.; Bozorg-Haddad, O.; Loáiciga, H.A. A State-Of-The-Art Review of Water Diplomacy. Environ. Dev. Sustain. 2020, 14, 1-21. [CrossRef]

45. Arbitral Tribunal. Lake Lanoux Arbitration (France v. Spain). Award of 16 November 1957.

46. McCaffrey, S. The Law of International Watercourses, 3rd ed.; Oxford University Press: Oxford, UK, 2019.

47. ICJ. Certain Activities Carried Out by Nicaragua in the Border Area (Costa Rica v. Nicaragua) and Construction of a Road in Costa Rica along the San Juan River (Nicaragua v. Costa Rica). Judgment, I.C.J. Reports, 665, 2015.

48. Spijkers, O. Sustainable Management of Freshwater Resources: Linking International Water Law and the Sustainable Development Goals. GAIA-Ecol. Perspect. Sci. Soc. 2019, 28, 135-142. [CrossRef]

49. Moermond, J.O., III; Shirley, E. A Survey of the International Law of Rivers. Denver J. Int. Law Policy 2020, 16, 139-159.

50. International Law Association. The Helsinki Rules on the Uses of the Waters of International Rivers. In Proceedings of the 52nd Conference, Helsinki, Finland, 14 August 1966.

51. Krieger, H.; Peters, A.; Kreuzer, L. Due Diligence in the International Legal Order; Oxford University Press: Oxford, UK, 2020.

52. Tignino, M.; Bréthaut, C. The Role of International Case Law in Implementing the Obligation Not to Cause Significant Harm. Int. Environ. Agreem. Politics Law Econ. 2020, 13, 1-18. [CrossRef]

53. Ellis, J. Liability for International Environmental Harm; Oxford University Press: Oxford, UK, 2013.

54. United Nations Food and Agriculture Organization. Proceedings of the FAO Regional Conference for Asia and the Pacific, Setting Regional Priorities to Manage Water for Agriculture under Conditions of Water Scarcity, APRC/20/3, Thimphu, Bhutan, 1-4 September 2020. 
55. D'Odorico, P.; Chiarelli, D.D.; Rosa, L.; Bini, A.; Zilberman, D.; Rulli, M.C. The Global Value of Water in Agriculture. Proc. Natl. Acad. Sci. USA 2020, 117, 21985-21993. [CrossRef] [PubMed]

56. Hildering, A. The Impact of a Human Right to Water on the Sustainable Balance of Water Uses under the UN Watercourses Convention. Utrecht Law Rev. 2020, 16, 7-17. [CrossRef]

57. International Law Commission. Comments and observations received from the United Kingdom, UN Doc. A/CN.4/447. In Yearbook of the International Law Commission; International Law Commission: Geneva, Switzerland, 15 January 1993; Volume II, Part One.

58. International Law Association. The Berlin Rules on Water Resources. In Proceedings of the International Law Association Reports of Conferences, Berlin, Germany, 21 August 2004; Volume 71.

59. United Nations General Assembly. International Covenant on Economic, Social, and Cultural Rights General Comment No. 15: The Right to Water (Arts. 11 and 12 of the Covenant), E/C.12/2002/11. In Proceedings of the Twenty-ninth Session of the Committee on Economic, Social and Cultural Rights, New York, NY, USA, 20 January 2003.

60. Langford, M.; Russell, A.F. The Human Right to Water: Theory, Practice and Prospects; Cambridge University Press: Cambridge, UK, 2017.

61. Spijkers, O. The Sustainable Human Right to Water as Reflected in the Sustainable Development Goals. Utrecht Law Rev. 2020, 16, 18-32. [CrossRef]

62. Murillo Chavarro, J. Extraterritorial Application of the Human Right to Water in a Transboundary Watercourse Context. In The Human Right to Water: A Legal Comparative Perspective at the International, Regional and Domestic Level; Intersentia: Cambridge, UK, 2015; pp. 283-340.

63. United Nations. Rio Declaration on Environment and Development, UN Doc. A/CONF.151/26/Rev.1 (Vol. I), Annex I. In Proceedings of the United Nations Conference on Environment and Development, 12 August 1992; United Nations Publication: New York, NY, USA, 1992. 